\title{
KAWIN HAMIL DAN IMPLIKASINYA TERHADAP HAK KEPERDATAAN ANAK ZINA MENURUT KHI, HUKUM POSITIF DAN HUKUM ISLAM
}

\author{
Armaya Azmi ${ }^{1}$ \\ ${ }^{1}$ Kantor Urusan Agama Kecamatan Binjai Utara
}

Balai Diklat Keagamaan Medan Jl. TB. Simatupang No. 122 Medan Telp. (061)8456256 E-mail Penulis: armayaazmi@gmail.com Naskah diterima: 11 April 2021 Naskah Direvisi: 12-20 April 2021 Naskah disetujui: 30 April 2021 Website Journal: http://apicbdkmedan.kemenag.go.id

\begin{abstract}
ABSTRAK
Kawin hamil akibat zina memiliki konsekuensi yang berdampak terhadap keabsahan pernikahan maupun status keperdataan anak yang dilahirkan. Diskursus tentang kawin hamil dan anak zina terus menjadi perbincangan yang tak pernah selesai. Apakah boleh seorang lelaki menikahi wanita yang sedang hamil? bagaimana hak keperdataan anak yang dilahirkan? Kepada siapa nasabnya disandarkan? Apakah ia berhak mewarisi harta ayah ibunya? Apakah suami dari ibunya berhak untuk menjadi wali nikahnya? Perbedaan cara pandang menyebabkan perbedaan dalam menyikapi masalah kawin hamil dan anak zina. Penelitian ini berusaha mengungkap masalah kawin hamil dan implikasinya terhadap anak yang dilahirkan, dari sudut pandang Kompilasi Hukum Islam sebagai produk fikih Indonesia, juga melihat dari sisi hukum Positif serta mengkajinya dalam perspektif hukum Islam, lalu memberikan analisis dan perbandingan dari berbagai sudut pandang tersebut
\end{abstract}

Kata kunci: Kawin hamil, Hak Keperdataan, Anak zina

\begin{abstract}
Pregnant marriage due to adultery has consequences that have an impact on the validity of marriage and the civil status of the child born. The discourse on pregnant marriage and adultery continues to be a never-ending conversation. Is it permissible for a man to marry a woman who is pregnant? How about the civil rights of children who are born? On whom was the lineage leaned? Is he entitled to inherit his mother's father's property? Does the husband of the mother have the right to be the guardian of marriage? Different perspectives cause differences in addressing the problem of pregnant marriage and adultery. This study seeks to reveal the problem of pregnant marriage and its implications for children born, from the perspective of the Compilation of Islamic Law as a product of Indonesian jurisprudence, also looking at positive law and studying it in the perspective of Islamic law, then providing analysis and comparisons from these various points of view.
\end{abstract}

Keywords: Pregnant marriage, civil rights, adultery child

\section{PENDAHULUAN}

Problematika yang sangat jama' ditemui di masyarakat terkait dengan hukum keluarga Islam secara umum atau perkawinan secara khusus adalah tentang kawin hamil dan implikasinya terhadap hukum keperdataan anak yang dilahirkan dari perkawinan tersebut. Maka kemudian muncul Istilah 'anak zina' yang dilekatkan kepada anak tersebut, yang sejatinya ia tidak memiliki dosa apapun atas kelahirannya, namun menanggung beban akibat dari perbuatan tercela antara perempuan dan laki-laki yang menghamilinya.

Di dalam Islam perbuatan zina adalah perbuatan tercela yang diharamkan oleh Allah. Dalam Q.S Al-Isra' 32 Allah menegaskan:

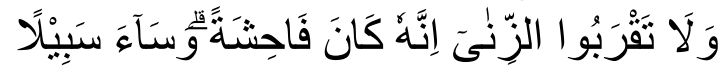


Dan janganlah kamu mendekati zina; (zina)

itu sungguh suatu perbuatan keji, dan suatu jalan yang buruk.

Allah tidak pernah mengharamkan sesuatu kecuali akan memberikan jalan keluar yang lebih baik daripada yang diharamkan tersebut. Allah tidak mungkin mengharamkan hubungan laki-laki dan perempuan, karena memang Allah menciptakan manusia berpasangan untuk kelangsungan kehidupan manusia. Oleh karenanya Allah menghalalkan Pernikahan sebagai jalan untuk menghindarkan manusia dari perzinaan. Allah mengharamkan zina adalah sebagai bentuk proteksi terhadap manusia, khususnya perempuan dan anak. karena mereka inilah yang akan menanggung langsung akibat dari hasil perbuatan tersebut. Sementara laki-laki yang menghamili bisa saja lari dari tanggungjawabnya karena ketiadaan komitmen.

Namun dalam realitasnya, praktikpraktik perzinaan menjadi sesuatu yang dianggap biasa dalam masyarakat khususnya bagi muda-mudi. Karena ketiadaan sanksi hukum yang membuat efek jera. Dalam sebuah survei Komnas Perlindungan Anak (CNN Indonesia, 2020) menyatakan bahwa 93,8 persen dari 4.700 siswi SMP/SMA di Jawa Barat, mengaku pernah berhubungan seksual. Dari survei tersebut terungkap bahwa 97\% dari responden mengaku pernah menonton pornografi.

Hubungan seksual yang dilakukan oleh anak di bawah umur ini pada akhirnya akan menyebabkan kehamilan. Hal ini mendorong anak untuk melakukan aborsi karena tidak sanggup untuk menahan beban psikologis dan sosial, sebagian lain memilih untuk melakukan pernikahan dini. Sebagai contoh kasus peningkatan Angka pernikahan dini dapat dilihat pada Pengadilan Agama (PA) Kabupaten Blora, Jawa Tengah. pada 2020 terdapat sebanyak 237 ABG di bawah umur mengajukan dispensasi kawin dan yang diputus sebanyak 220 pasangan. Hal ini menurut Kastari sebagai Panitera Muda Hukum karena kebanyakan hamil duluan, pacaran tidak tahu aturan dan akhirnya kejadian, dinikahkan meski belum umur 19 tahun. (Liputan6.com, 2020).

Fenomena-fenomena kawin hamil kemudian menjadi sesuatu yang biasa terjadi dalam masyarakat, khususnya bagi remaja. Maka lantas yang sering menjadi pertanyaan adalah bagaimana keabsahan kawin hamil? lalu bagaimana status anak yang dilahirkan kemudian? apakah ia menjadi anak yang sah bagi ayah ibunya, atau ia hanya bernasab kepada ibunya? Apakah ia berhak mewarisi harta ayah ibunya? Apakah suami dari ibunya berhak untuk menjadi wali nikahnya?

Jawaban-jawaban terhadap masalahmasalah di atas menjadi perdebatan, karena perbedaan kacamata yang digunakan dalam menjawab persoalan tersebut. Ada menggunakan kacamata fiqh-fiqh klasik sebagai dasar hukumnya, adapula yang merujuk kepada fiqh Indonesia yaitu Kompilasi Hukum Islam (KHI) dan UU Perkawinan. Tulisan ini mencoba menganalisis permasalahan di atas dengan mengambil judul Kawin Hamil dan Implikasinya terhadap Hak Keperdataan Anak Zina (Kawin Hamil) Menurut KHI, UU Perkawinan dan Hukum Islam.

\section{METODOLOGI PENELITIAN}

Penelitian ini menggunakan metode penelitian kualitatif, untuk mendeskripsikan secara luas tentang permasalahan yang diangkat. Secara khusus penelitian ini menggunakan pendekatan yuridis-normatif. Untuk mengkaji secara jelas norma-norma hukum terkait permasalahan kawin hamil dan anak zina dengan melakukan teknik perbandingan hukum (comparative law). Antara hukum Islam, Hukum Positif dan KHI, dimana ketiganya merupakan sumber hukum yang diakui dalam sistem hukum di Indonesia.

Teknik pengumpulan data dilakukan dengan library research (telaah kepustakaan). 
Dengan menggali norma hukum dari sumber hukum baik Undang-Undang, Qanun, Fatwa, peraturan-peraturan dan lainnya.

Analisis data dilakukan secara induktif, dengan mengumpulkan fakta-fakta dan premispremis yang ada kemudian menarik kesimpulan sesuai dengan norma-norma hukum yang diketahui.

\section{HASIL DAN PEMBAHASAN}

\section{A. Kawin Hamil}

Secara etimologi Istilah "kawin hamil" terdiri dari dua kata yaitu : 1. Kawin. yang berarti membentuk keluarga dengan lawan jenis; bersuami atau beristri, dan 2. Hamil. Yang berarti mengandung janin dalam rahim karena sel telur dibuahi oleh spermatozoa. (Badan Pengembangan dan Pembinaan Bahasa, 2012)

Secara Terminologi kawil hamil didefinisikan oleh Abd. Rahman Ghazaly yaitu "kawin dengan seorang wanita yang hamil diluar nikah baik dikawini dengan laki-laki yang menghamilinya maupun dengan laki-laki bukan yang menghamilinya”. (Ghazaly, 2003) Sedangkan Zainuddin Ali mengatakan bahwa Perkawinan wanita hamil adalah seorang wanita yang hamil sebelum melangsungkan akad nikah, kemudian dinikahi oleh pria yang menghamilinya.

Secara umum wanita yang sedang hamil itu termasuk wanita yang diharamkan untuk dinikahi dalam waktu yang sementara. Jika sebab yang menghalangi itu sudah tidak ada maka barulah boleh menikah. Wanita hamil ini dapat dibagi kepada beberapa macam: 1. Wanita hamil yang sedang bersuami; 2 . Wanita hamil yang telah diceraikan oleh suaminya; 3 . Wanita hamil yang ditinggal mati suaminya; 4. Wanita hamil yang diakibatkan karena wati syubhat; 5. Wanita hamil karena zina.

Untuk jenis pertama yaitu wanita hamil

yang sedang bersuami. Maka Islam mengharamkan pernikahan seperti ini, karena tidak dibenarkan seorang istri bersuami lebih dari satu (poliandri). Sebagaimana dalam firman Allah SWT. (Q.S. an-Nisa: 24).

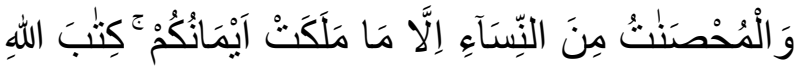

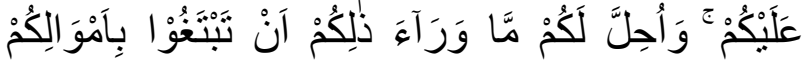

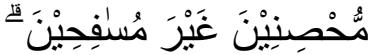

Dan (diharamkan juga kamu menikahi) perempuan yang bersuami, kecuali hamba sahaya perempuan (tawanan perang) yang kamu miliki sebagai ketetapan Allah atas kamu. .....

Kedua. Wanita hamil yang telah diceraikan oleh suaminya. Wanita hamil ini boleh dinikahi oleh laki-laki lain apabila masa iddahnya sudah selesai, yaitu sampai ia melahirkan anaknya. Sebagaimana firman Allah SWT dalam Q.S. at-Talaq: 4

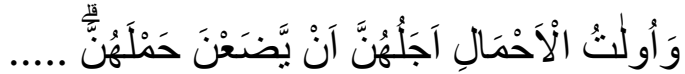

$$
\begin{aligned}
& \text {......Sedangkan perempuan-perempuan }
\end{aligned}
$$
yang hamil, waktu idah mereka itu ialah sampai mereka melahirkan kandungannya. ......

Ketiga. Wanita hamil yang ditinggal mati suaminya. Meskipun Madzhab Imamiyah berpendapat masa iddahnya adalah yang paling panjang diantara waktu melahirkan dan 4 bulan 10 hari. Namun Madzhab empat berpendapat bahwa iddah bagi wanita hamil yang ditinggal mati suaminya adalah sampai dia melahirkan bayinya. Sekalipun hanya beberapa saat dia ditinggal mati oleh suaminya dia sudah boleh menikah lagi sesudah lepas dari kehamilannya.

Keempat. Wanita hamil yang diakibatkan karena wati' syubhat. Imam Maliki, Hanafi, dan Imamiyah berpendapat bahwa wanita hamil yang dicampuri secara syubhat, maka iddahnya sampai ia melahirkan.

Kelima Wanita hamil karena zina. Hukum menikahkan wanita hamil ini masih ada perbedaan pendapat. Ada yang membolehkan dan ada juga yang tidak membolehkan. Inilah yang menjadi topik pembahasan pada tulisan ini 


\section{B. Kawin Hamil Menurut Fiqh}

Para ulama berbeda pendapat terkait dengan hukum perkawinan wanita hamil. Sebagian menganggap bahwa menikah dengan wanita hamil hukumnya boleh, sebagian menganggapnya terlarang.

\section{Mazhab Hanafi}

Ulama Hanafiyah berpendapat bahwa sah hukumnya melangsungkan perkawinan dengan wanita hamil bila yang menikahinya adalah laki-laki yang menghamilinya. Namun jika yang menikahi bukan laki-laki yang menghamilinya masih banyak perdebatan diantara kalangan madzhab tersebut.

Abu Hanifah dan Muhammad berpendapat bahwa walaupun bukan laki-laki yang menghamili wanita tersebut yang menikahinya pernikahannya tetap sah, tetapi laki-laki yang menikahi tersebut tidak boleh berhubungan seksual dengan perempuan yang menjadi istrinya itu sampai anak yang dikandungnya lahir.

Landasan hukum yang digunakan oleh Hanafiah adalah

1. Perempuan yang berzina tidak disebutkan di dalam kelompok para perempuan yang haram untuk dinikahi. Berarti dia boleh untuk dinikahi. Berdasarkan firman Allah SWT,.....dan dihalakan bagi kamu yang demikian itu." (an-Nisā': 24)

2. Tidak ada kehormatan bagi air sperma zina. Dengan dalil bahwa perbuatan zina ini tidak menetapkan nasab, berdasarkan hadits الولا للفراش و للعاهر الحجر,

anak bagi yang membuat hamil ibunya dan anak yang lahir dari pelacur tidak dapat dinasabkan kepada pelaku yang menghamilinya.

Jika perbuatan zina tidak mengandung unsur kehormatan, maka perbuatan zina ini tidak menjadi penghalang bagi pembolehan nikah. Sesungguhnya larangan untuk menggauli perempuan yang hamil akibat perbuatan zina sampai dia melahirkan anak berdasarkan sabda Rasulullah saw:

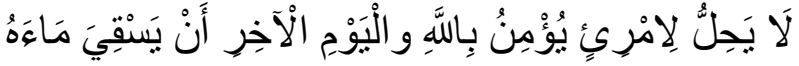

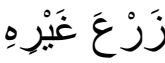

"tidak dihalalkan bagi orang yang beriman kepada Allah dan hari akhir untuk menyiramkan airnya kepada tanaman orang lain. (H.R. Abu Dawud dan Imam Tirmidzi).

Imam Muhammad bin Al Hasan AsySyaibani juga sependapat dengan imam Abu Hanifah bahwa perkawinannya sah, akan tetapi diharamkan mengadakan senggama hingga bayi yang dikandungnya itu lahir.

\section{Mazhab Syafii}

Hampir Senada dengan Mazhab Hanafi, Imam Syafi'i menyatakan bahwa kawin hamil adalah sah dan boleh hukumnya, karena adanya janin tidak merusak akadnya suatu perkawinan. Namun berbeda dengan Hanafi yang melarang untuk berhubungan seksual sampai bayi yang dikandung lahir, Imam Syafi'i mengatakan menyetubuhi wanita hamil tersebut hukumnya boleh, sebab tidak mungkin nasab bayi yang dikandungnya itu tidak akan ternodai dengan sperma suaminya dan jika mereka tidak terikat dengan perkawinan lain, maka itu dianggap sah.

Menurut Imam Syafi'i hubungan seksual karena zina itu tidak ada iddahnya, wanita yang hamil karena zina itu boleh dikawini, dan boleh melakukan hubungan seks sekalipun dalam keadaan hamil". Dalil yang digunakan adalah firman Allah dalam surah Alnur ayat 32

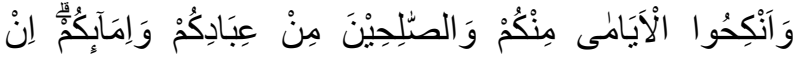

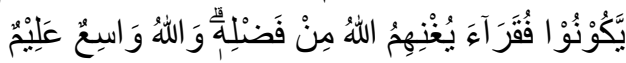

"Dan nikahkanlah orang-orang yang masih membujang di antara kamu, dan juga orang-orang yang layak (menikah) dari hamba-hamba sahayamu yang laki-laki dan perempuan. Jika mereka miskin, Allah akan memberi kemampuan kepada mereka dengan karunia-Nya. Dan Allah Mahaluas (pemberian-Nya), Maha Mengetahui. 
Ayat di atas menjelaskan bahwa orang yang berzina adalah termasuk dalam golongan yang belum menikah, sehingga tidak ada keharaman menikahinya walaupun dalam keadaan hamil. Karena wanita tersebut tidak terikat perkawinan dengan orang lain, dan boleh mengumpulinnya karena nasab bayi yang dikandungnya tidak mungkin tercampur atau ternodai oleh sperma suaminya yang bukan menghamilinya.

Imam An-Nawawi menyatakan bahwa Jika ada seorang perempuan yang berzina tidak diharamkan atas laki-laki itu untuk menikahinya. Firman Allah SWT:

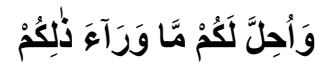

(dan dihalakan bagi kamu yang demikian itu).

Dalam sebuah hadits riwayat Aisyah r.a, bahwa Nabi SAW pernah ditanya oleh seorang laki-laki ia berzina dengan perempuan maka ia ingin menikahi perempuan itu atau anak perempuannya, maka Rasul menjawab: "tidaklah yang haram itu mengharamkan yang halal, sesungguhnya yang diharamkan itu bukan karena nikahnya". Jika wanita pezina tersebut datang dengan membawa anak perempuannya, lalu Imam asy-Syafie $i$ yang dirahmati Allah mengatakan: "makruh apabila ada yang menikahi wanita tersebut, jika tetap ingin menikahinya maka pernikahannya tidak batal.

An-Nawawi menganggap bahwa wanita yang hamil dari hasil perzinahan tidak dikenakan ketentuan-ketentuan hukum sebagaimana ketentuan yang diterapkan dalam pernikahan yang sah secara syariat. adapun pemberlakuan iddah adalah untuk menjaga kesucian nasab dan menghargai sperma. Akan tetapi dalam kasus perzinahan, sperma laki-laki pezina tidak dihargai, dan kehamilan yang terjadi di luar pernikahan, nasab anaknya kepada ibu yang mengandungnya. Sebagaimana sabda Rasulullah "Sesuatu perbuatan yang haram tidak dapat mengharamkan yang halal'. Sehingga kesimpulannya ulama Syafiiyah berpendapat bahwa menikahi wanita hamil sah, walaupun yang menikahi bukan laki-laki yang menghamilinya.

\section{Mazhab Maliki}

Mazhab Maliki berpendapat, tidak boleh dilaksanakan akad terhadap perempuan yang melakukan perbuatan zina sebelum dia dibebaskan dari zina dengan tiga kali haid, atau setelah lewat masa tiga bulan. Jika dilaksanakan akad pernikahan kepadanya sebelum dia dibebaskan dari zina, maka akad pernikahan ini adalah sebuah akad yang fasid. Akad ini harus dibatalkan, baik muncul kehamilan ataupun tidak. Sedangkan alasan karena munculnya kehamilan, berdasarkan hadits: "Jangan sampai dia siramkan air spermanya kepada janin milik orang lain". Sedangkan alasan yang kedua adalah karena rasa takut akan terjadinya percampuran nasab.

Selain itu menurut Imam Malik bahwa pernikahan memiliki kehormatan. Diantara kehormatannya adalah bahwa dia tidak boleh dituangkan pada air perzinahan, sehingga yang haram bercampur dengan yang halal dan air kehinaan berbaur dengam air kemuliaan.

\section{Mazhab Hambali}

Mazhab Hambali berpendapat jika seorang perempuan melakukan perbuatan zina, maka bagi orang yang mengetahui hal itu tidak boleh menikahinya, kecuali dengan dua syarat:

Pertama: Masa iddahnya telah selesai. Jika dia hamil akibat perbuatan zina, maka berakhirnya masa iddahnya adalah dengan melahirkan anaknya dan dia tidak boleh dinikahi sebelum dia melahirkan anaknya. Berdasarkan hadits "Jangan kamu gauli perempuan hamil sampai dia melahirkan."

Kedua: dia bertobat dari perbuatan zina, berdasarkan Q.S An-Nur :3

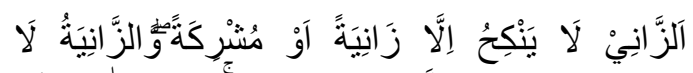

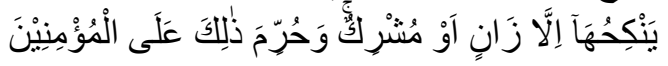

Pezina laki-laki tidak boleh menikah kecuali dengan pezina perempuan, atau dengan perempuan musyrik; dan pezina perempuan tidak boleh menikah kecuali 
dengan pezina laki-laki atau dengan laki-laki musyrik; dan yang demikian itu diharamkan bagi orang-orang mukmin.

Ayat ini mengharamkan untuk menikahi pezina yaitu sebelum melakukan tobat dalam hukum zina. jika dia bertobat, maka hilang pengharaman berdasarkan sabda Nabi SAW.,

$$
\text { التائب من الذنب كمن لا ذنب له }
$$

"orang yang bertobat dari dosa bagaikan orang yang tidak berdosa.

Ibnu Qudamah yang merupakan salah satu ulama madzhab Hanbali mengatakan bahwa hukum perkawinan wanita hamil karena zina tidak boleh dilakukan saat wanita tersebut dalam keadaan hamil. Karena menurut Ibnu Qudamah bahwa wanita yang telah melakukan persetubuhan di luar pernikahan harus tetap menjalani masa iddah. Setelah ia selesai menjalani masa iddahnya, wanita tersebut belum boleh melakukan pernikahan karena ia harus menjalani syarat yang kedua yaitu bertaubat dengan sungguh-sungguh.

\section{Kawin Hamil Menurut KHI}

Dalam Kompilasi Hukum Islam, kawin hamil dijelaskan dalam Pasal 53 KHI. Pasal tersebut menjelaskan tentang kebolehan melangsungkan perkawinan bagi wanita hamil di luar nikah. Meskipun demikian, ada ketentuan yang harus dipenuhi dalam perkawinan tersebut, diantaranya:

1. Seorang wanita hamil di luar nikah bisa dikawinkan dengan pria yang menghamilinya.

2. Perkawinan dengan wanita hamil yang disebut pada ayat (1) dapat dilangsungkan tanpa menunggu lebih dahulu kelahiran anaknya.

3. Dengan dilangsungkannya perkawinan pada saat wanita hamil, tidak diperlukan perkawinan ulang setelah anak yang dikandung lahir.

Ketentuan hukum yang terdapat pada Pasal 53 KHI ini sering menuai perdebatan dan perbedaan pendapat. Pendapat yang cenderung mutasyaddid (ketat dan keras dalam bersikap) akan merasa keberatan dengan ketentuan ini yang dinilai terlalu longgar dan cenderung kompromistis terhadap perzinaan. Alih-alih memberikan hukuman bagi pelaku zina, Pasal 53 KHI tersebut justru memberikan perlindungan dan menutupinya. Hal ini kontras dengan hukum syariat yang mewajibkan hukuman terhadap pelaku zina, yaitu hukuman cambuk seratus kali bagi pelaku zina ghairu muhsan (yang belum menikah) dan hukuman rajam sampai mati bagi pelaku zina muhsan (yang sudah menikah).

Kendati demikian, menurut Nurul Huda ketentuan Pasal 53 KHI tersebut juga berpegangan pada alasan logis dan bisa dijadikan landasan hukum untuk diterapkan dalam tatanan kehidupan masyarakat di Indonesia. Kebolehan melangsungkan perkawinan bagi wanita hamil menurut ketentuan Pasal 53 KHI, secara tegas dibatasi pada perkawinan dengan laki-laki yang menghamilinya.

Paling tidak ada tiga (3) faktor yang bisa menjadi landasan hukum lahirnya ketentuan pasal 53 ini:

a. Faktor filosofis

Ketentuan Pasal 53 tersebut mempunyai landasan filosofis untuk melindungi kelangsungan hidup wanita hamil di luar nikah, sekaligus menjaga kelangsungan hidup anaknya, agar kelak setelah lahir dapat melangsungkan kehidupannya secara normal dan tidak kehilangan haknya sebagai manusia secara individu maupun sebagai anggota masyarakat. kebolehan wanita hamil di luar nikah menikah dengan laki-laki yang menghamilinya, adalah untuk menghindari dampak negatif lain yang akan diterima khususnya oleh wanita dan anak sebagai pihak yang paling merasakan akibatnya.

Keberadaan ketentuan Pasal 53 KHI tersebut sekaligus menjadi landasan bagi pihak wanita untuk menuntut pihak lakilaki agar bersedia bertanggung jawab, dan diwujudkan 
dengan melangsungkan perkawinan serta menjalankan kewajibannya sebagai suami sebagaimana dalam keluarga yang normal.

\section{b. Faktor Sosiologis}

Di Indonesia, sebelumnya tidak terdapat hukum tertulis perihal penyelesaian wanita hamil di luar nikah. Masyarakat biasanya menggunakan penyelesaian dengan cara melangsungkan perkawinan antara wanita hamil tersebut dengan laki-laki yang menghamilinya tanpa menunggu kelahiran anak yang dikandung. Cara ini bertujuan untuk menutup aib agar tidak diketahui masyarakat luas. Selama para pelaku zina dan keluarga mampu menjaga rahasia itu, maka para pezina dan juga anaknya akan selamat dari respons masyarakat. Masyarakat dalam merespons perzinaan biasanya dengan melakukan pengasingan atau pengisolasian terhadap pelaku zina, keturunan, dan bahkan kepada keluarganya sekalipun. Respons masyarakat tersebut tentu tidak memanusiakan pelaku zina, keluarga, bahkan anak yang semestinya tidak melakukan dosa namun harus menerima hukuman itu.

Ketentuan kawin hamil dalam pasal 53 KHI tersebut secara sosiologis dapat dikatakan mengadopsi penyelesaian masyarakat dengan cara melangsungkan perkawinan antara pasangan zina tersebut. Sistem adopsi tersebut didukung oleh realitas sejarah yang menunjukkan bahwa produk-produk pemikiran yang sering dianggap sebagai hukum Islam itu tidak lebih merupakan hasil interaksi antar pemikir hukum dengan lingkungan sosiokultural atau sosio-politik yang mengitarinya Sistem adopsi ini juga didukung kaidah ushul fiqh yang mengatakan: "al-'ādatu muhakkamah" (Adat kebiasaan itu bisa menjadi hukum). Melalui langkah ini maka ketentuan Pasal 53 KHI ini mempunyai landasan sosiologis yang kuat, sehingga akan efektif diterapkan dalam masyarakat Indonesia.

\section{c. Faktor Psikologis}

Pada dasarnya, kehamilan seorang wanita karena zina merupakan kehamilan yang tidak diinginkan. Pada situasi ini, pihak yang paling merasakan tekanan psikologis yang sangat kuat adalah wanita. Jika tidak segera dilangsungkan perkawinan dengan laki-laki yang menghamilinya, maka dikhawatirkan situasi lebih buruk akan terjadi. Seperti bunuh diri dan aborsi biasanya didominasi oleh tekanan psikologis akibat kehamilan di luar nikah. Kedua kasus tersebut bisa terjadi karena wanita merasa hidupnya tidak nyaman, selalu dihantui rasa malu, rendah diri, perasaan berdosa, depresi, pesimis, dan sebagainya.

Namun ternyata, jika kemudian wanita hamil tersebut tetap menjalani kehidupannya seperti semula dan memilih menjadi orang tua tunggal (single parent), langkah itu juga tidak mampu memberi garansi bagi kesehatan mental pada anak. Seperti ibunya, anak juga akan mendapatkan tekanan psikologis yang sama. Perkembangan psikologis anak menjadi tidak sehat selain karena faktor aib latar belakang kelahirannya sehingga eksistensinya dilabeli sebagai "anak haram", juga karena disebabkan faktor realitas keluarganya yang tidak utuh. Realitas tersebut tentu akan menjadi dampak lanjut, karena keutuhan keluarga juga menjadi faktor yang mempengaruhi perkembangan psikologis dan sosial seorang anak.

Dalam perkembangan hidup seperti itu, anak tidak mendapatkan kasih sayang dan perhatian, karena hanya mendapatkan kasih sayang secara sepihak dari ibunya. Dalam situasi yang timpang ini tidak menutup kemungkinan anak tersebut menjadi pribadi yang pesimis, rendah diri, atau bahkan kelak justru berubah menjadi kejam karena merasa ditelantarkan bapaknya. Problem lanjut inilah yang menjadi landasan psikologis perlu ditetapkan ketentuan Pasal 53 KHI tersebut. Perspektif psikologis tersebut memperlihatkan bahwa ketetapan Pasal 53 KHI tersebut ditujukan untuk melakukan upaya preventif guna mencegah terjadinya problem lanjut dan sudah barang tentu akan menimbulkan persoalan baru bagi upaya pembangunan 
kesehatan bangsa yang meliputi, kesehatan jasmani dan kesehatan mental bangsa.

Ketentuan tentang kawin hamil dalam KHI pasal 53 tersebut memiliki hujjah yang logis dan tidak keluar dari pendapat-pendapat ulama fiqh yang membolehkan perkawinan wanita hamil, Terlepas dari perbedaan pendapat. Perbandingan pendapat dalam perspektif fiqh dan KHI dapat dilihat pada tabel berikut ini.

\section{Perkawinan Wanita Hamil Dalam Perspektif Fiqh dan KHI}

\begin{tabular}{|c|l|}
\hline HUKUM KAWIN HAMIL & \multicolumn{1}{|c|}{ KETENTUAN } \\
\hline $\begin{array}{c}\text { HANAFI : } \\
\text { Boleh }\end{array}$ & $\begin{array}{l}\text { hanya diperbolehkan dengan laki-laki yang menghamilinya, Apabila yang menikahi } \\
\text { laki-laki lain yang tidak menghamilinya, maka laki-laki tersebut tidak boleh } \\
\text { berhubungan seksual dengan wanita yang hamil tersebut sebelum anak yang } \\
\text { dikandungnya lahir }\end{array}$ \\
\hline $\begin{array}{c}\text { MALIKI : } \\
\text { Tidak memperbolehkan }\end{array}$ & $\begin{array}{l}\text { tidak boleh dilaksanakan akad terhadap perempuan yang melakukan perbuatan zina } \\
\text { sebelum dia dibebaskan dari zina dengan tiga kali haid, atau setelah lewat masa tiga } \\
\text { bulan }\end{array}$ \\
\hline SYAFI : & $\begin{array}{l}\text { tidak memberikan syarat apapun. hubungan seksual karena zina itu tidak ada } \\
\text { iddahnya, wanita yang hamil karena zina itu boleh dikawini, dan boleh melakukan } \\
\text { hubungan seks sekalipun dalam keadaan hamil }\end{array}$ \\
\hline HANBALI & $\begin{array}{l}\text { Tidak memperbolehkan kecuali dengan 2 syarat, yaitu: } \\
\text { Tidak memperbolehkan }\end{array}$ \\
\hline KHI & $\begin{array}{l}\text { Dibolehkan kawin dengan pria yang menghamilinya, tanpa menunggu lebih dahulu } \\
\text { kelahiran anaknya. dan tidak diperlukan perkawinan ulang setelah anak yang } \\
\text { dikandung lahir }\end{array}$ \\
\hline Boleh &
\end{tabular}

\section{Faktor-Faktor Terjadinya Kawin Hamil}

Terjadinya peristiwa hamil diluar nikah, selain karena adanya pergaulan bebas, juga karena lemahnya iman pada masing-masing pihak. Oleh karenanya untuk mengantisipasi perbuatan yang keji dan terlarang itu, pendidikan agama yang mendalam dan kesadaran hukum semakin diperlukan oleh setiap individu. Adapun sejumlah faktor yang menyebabkan terjadinya hubungan seksual diluar nikah menurut Sarlito sebagaimana dikutip Haeratun adalah:

1. Banyaknya rangsangan pornografi baik yang berupa film,bahan bacaan,mau- pun yang berupa obrolan sesama teman sebaya, yang merupakan akibat dari arus globalisasi

2. Tersedianya kesempatan untuk melakukan perbuatan seks. Misalnya pada waktu orang tua tidak ada di rumah, di dalam mobil, atau pada saat piknik.

Menurut Dr. Muhammad Abduh Malik penyebab hamil di luar nikah sama dengan timbulnya perilaku perzinahan. Faktor penyebab tersebut terdiri dari faktor internal dan faktor eksternal, yaitu:

1. Faktor Internal

Secara naluriah manusia memiliki nafsu syahwat terhadap lawan jenisnya. Apabila nafsu syahwat itu begitu besar, maka akan dapat mengalahkan akal budinya atau akal sehat dan kendali normalnya. Artinya jika akal sehat dan keyakinan moral tidak cukup kuat untuk mengendalikan gejolak nafsu syahwat maka manusia tersebut akan terjerumus kepada perbuatan zina, apabila mereka tidak menempuh jalur pernikahan yang sah.

2. Faktor Eksternal

Terdapat dua faktor eksternal yang memungkinkan untuk terjadinya pernikahan hamil di luar nikah yaitu:

a. Kondisi sosial

Faktor eksternal yang mendorong manusia untuk melakukan perbuatan zina adalah disebabkan kondisi sosial yang mentolerir pergaulan bebas antara pria dan 
wanita. Adat istiadat yang dahulunya memandang tabu pergaulan bebas antara pria dan wanita, kini menjadi semakin longgar.

\section{b. Aturan hukum pidana yang sangat lemah}

Aturan hukum pidana dalam kitab undang-undang hukum pidana (KUHP) tidak mencantumkan hubungan seksual di luar pernikahan yang sah yang dilakukan oleh bujang dan gadis atau orang-orang yang tidak terikat pernikahan yang dilakukan atas dasar suka sama suka sebagai perbuatan zina dan perbuatan zina yang ada dalam KUHP dimasukkannya ke dalam delik aduan absolut. Akibatnya sebagai anggota masyarakat, tidak takut melakukan perbuatan zina atau hubungan seks di luar pernikahan yang sah karena tidak ada atau tidak pasti adanya aturan hukum positif yang akan menjeratnya.

\section{E. Anak Zina}

Anak Zina adalah anak yang lahir akibat zina. Al-Jurzani dalam al-Ta'rifät, mendefinisikan zina dengan "al-wath'u $f i$ qubulin khalin 'an milkin wa syubhatin" "Memasukkan alat kelamin pria (zakar) ke dalam alat kelamin perempuan (faraj) yang bukan miliknya (bukan istrinya) dan tidak ada unsur syubhat (keserupaan atau kekeliruan)."

Dalam Kamus Bahasa Indonesia, zina didefinisikan dengan dua hal: 1) Hubungan antara laki-laki dan perempuan tidak dalam ikatan perkawinan yang sah. 2) Hubungan badan dari laki-laki yang memiliki ikatan perkawinan dengan perempuan yang bukan istri sahnya, atau dari perempuan yang memiliki ikatan perkawinan dengan laki-laki yang bukan suami sahnya.

Dari pengertian ini, yang pertama dalam fiqh disebut dengan zina ghairu muhsan sedangkan yang kedua disebut dengan zina muhsan. hukuman terhadap zina muhsan adalah dilempar batu (rajm) sampai mati, dan sanksi terhadap zina ghairu muhsan adalah hukuman cambuk sebanyak seratus kali.

Anak zina di dalam Fatwa MUI didefinisikan sebagai berikut: "Anak hasil zina adalah anak yang lahir sebagai akibat dari hubungan badan di luar pernikahan yang sah menurut ketentuan agama, dan merupakan jarimah (tindak pidana kejahatan)".

Oleh J. Satrio anak hasil zina didefinisikan sebagai anak-anak yang dilahirkan dari hubungan luar nikah antara seorang laki-laki dan seorang perempuan dimana salah satu atau kedua-keduanya terikat perkawinan dengan orang lain. Dalam referensi lain disebutkan anak zina adalah anak yang dilahirkan atau dibenihkan dari hubungan seorang pria dan seorang wanita yang keduanya atau salah satunya terikat pernikahan dengan orang lain.

Menurut Munir Fuady (penulis buku Konsep Hukum Perdata) dalam KUH Perdata anak zina adalah anak yang lahir dari hubungan intim (tanpa nikah) antara seorang seorang laki-laki dengan perempuan dimana salah seorang atau kedua-duanya terikat perkawinan dengan orang lain. Dalam hal ini, anak tersebut tidak dapat dijadikan anak diakui maupun anak angkat.

Dalam pengertian ini, istilah anak zina dalam hukum positif adalah bentuk dari anak yang dilahirkan akibat zina muhsan.dimana salah satu pasangan zina atau kedua-duanya terikat dengan perkawinan. Sementara dalam status anak hasil zina pasangan yang belum menikah (ghairu muhsan) dikenal dengan istilah anak luar nikah.

Di dalam Undang-undang Perkawinan no. 1 tahun 1974 terdapat tiga istilah yang berkaitan dengan anak.

1. Anak yang sah. Dijelaskan pada pasal 42 yaitu anak yang dilahirkan dalam atau sebagai akibat perkawinan yang sah.

2. Anak di luar Perkawinan. Dijelaskan pada pasal 43

3. Anak Zina. Pada pasal 44 dijelaskan bahwa Seorang suami dapat menyangkal sahnya anak yang dilahirkan oleh isterinya, bilamana ia dapat membuktikan bahwa isterinya telah berzina dan anak itu akibat dari perzinaan tersebut. 
Dalam definisi ini, terdapat perbedaan istilah antara anak zina dalam UU Perkawinan dan Hukum Islam. Anak zina dalam Undangundang memiliki konotasi dengan anak li'an yaitu tuduhan suami terhadap istrinya bahwa anak yang dilahirkannya adalah hasil perselingkuhan dengan orang lain.

\section{F. Hak-Hak Keperdataan Anak Hasil Zina}

\section{Hak Nasab}

\section{a. Menurut Hukum Islam}

Seorang anak tidak dapat dinasabkan kepada bapaknya sebagai anak yang sah, jika anak dilahirkan kurang dari enam bulan setelah akad nikah. Karena sependek-pendeknya tenggang waktu yang harus ada antara kelahiran anak dan perkawinan adalah enam bulan. Artinya jika anak lahir tiga bulan setelah orangtuanya menikah, anak tersebut tidak dapat dinasabkan kepada bapaknya sebagai anak yang sah. Menurut Wahbah Zuhaili Sebab penentuan nasab seorang anak dari ibunya adalah dengan kelahiran, baik secara syar'i maupun tidak. Adapun sebab-sebab penentuan nasab anak dari ayahnya adalah sebagai berikut.

1) Pernikahan yang sah

Para fuqaha sepakat bahwa anak yang terlahir dari rahim seorang wanita dengan jalan pernikahan yang shahih atau sah, nasabnya dikembalikan kepada suami wanita tersebut. Dalilnya hadits yang berbunyi, "al-waladu li al-firas" "Nasab seorang anak itu dinisbahkan kepada kedua orang tuanyayang melakukan persetubuhan dalam pernikahan yang sah." Maksud kata firasy dalam hadits tersebut adalah istri yang telah digauli. Akan tetapi, penentuan nasab dalam hal ini harus sesuai dengan syarat-syarat sebagai berikut.

Syarat Pertama, sang suami termasuk orang yang secara adat sudah mampu menghamili istri.

Syarat kedua, kelahiran anak terjadi setelah enam bulan dari waktu nikah menurut pendapat ulama Hanafiyyah, dan dari pertama sanggama setelah nikah menurut pendapat mayoritas ulama. jika anak tersebut dilahirkan kurang dari batas minimal masa kehamilan, yaitu enam bulan maka para ulama sepakat bahwa nasab anak tersebut tidak diikutkan pada suami.

Syarat ketiga, keadaan yang memungkinkan pertemuan kedua mempelai secara langsung setelah akad nikah

2) Pernikahan Fasid

Penisbatan nasab anak dalam pernikahan fasid sama seperti dalam pernikahan yang sah karena penentuan nasab dapat menjaga kelangsungan hidup bagi anak itu sendiri. Penentuan nasab dalam pernikahan fasid disyaratkan tiga hal: a). Suami termasuk orangyang mampu menghamili, yaitu dengan usia yang sudah baligh; b). Sudah jelas melakukan hubungan suami istri; c) pihak wanita melahirkan setelah enam bulan atau lebih. Jika istri melahirkan anak sebelum lewat enam bulan dari dukhul dan khalwat, nasab anak tidak diikutkan pada pihak lelaki, karena itu menjadi bukti bahwa anak itu berasal dari benih lelaki lain.

\section{3) Wathi 'Syubhat}

Yaitu hubungan sanggama selain zina, namun juga bukan dalam bingkai pernikahan yang sah ataupun fasid. Contohnya seperti seorang suami menggauli perempuan yang berada di atas tempat tidurnya dan perempuan itu dikira istrinya tapi ternyata bukan.

jika kemudian pihak wanita melahirkan anak setelah lewat enam bulan atau lebih dari waktu sanggama, nasab anak tersebut diikutkan pada orang yang menggaulinya, karena jelas kehamilannya disebabkan olehnya. Akan tetapi jika kelahirannya itu sebelum lewat enam bulan dari waHu sanggama, nasab anak tersebut tidak diikutkan pada pihak lelaki yang menggaulinya, karena jelas wanita tersebut hamil sebelum melakukan sanggama bersamanya. Kecuali, jika memang pihak lelaki mengaku bahwa anak tersebut adalah anaknya sendiri, karena bisa jadi ia telah menggauli wanita tersebut sebelumnya. 
Tiga hal di atas yang dapat menentukan nasab seorang anak kepada ayahnya. Sedangkan jika hubungan badan yang dilakukan itu termasuk kategori zina, nasab anaknya tidak diikutkan pada pihak yang melakukan zina. Dalilnya hadits Nabi "Nasab seorang anak dinisbahkan kepada kedua orangtuanya yang melakukan persetubuhan dalam pernikahan yang sah, sedangkan bagian bagi yang berzina itu batu," karena zina itu perbuatan yang dilarang oleh syariat sehingga tidak berhak menjadi sebab untuk merasakan nikmatnya nasab.

Ijma' Ulama juga menyatakan apabila ada seseorang berzina dengan perempuan yang memiliki suami, kemudian melahirkan anak, maka anak tidak dinasabkan kepada lelaki yang menzinainya, melainkan kepada suami dari ibunya tersebut, dengan ketentuan ia tidak menafikan anak tersebut. Umat telah ijma' (bersepakat) tentang hal itu dengan dasar hadis Nabi saw, dan Rasul saw menetapkan setiap anak yang terlahir dari ibu, dan ada suaminya, dinasabkan kepada ayahnya (suami ibunya), kecuali ia menafikan anak tersebut dengan li'an, maka hukumnya hukum li'an.

Juga disampaikan oleh Imam Ibnu Qudamah dalam Kitab al-Mughni sebagai berikut: Para Ulama bersepakat (ijma') atas anak yang lahir dari ibu, dan ada suaminya, kemudian orang lain mengaku (menjadi ayahnya), maka tidak dinasabkan kepadanya.

Pendapat Jumhur Madzhab Fikih Hanafiyyah, Malikiyyah, Syafi'iyyah, dan Hanabilah yang menyatakan bahwa prinsip penetapan nasab adalah karena adanya hubungan pernikahan yang sah. Selain karena pernikahan yang sah, maka tidak ada akibat hukum hubungan nasab, dan dengan demikian anak zina dinasabkan kepada ibunya, tidak dinasabkan pada lelaki yang menzinai.

Dalam Fatwa Majelis Ulama Indonesia Nomor: 11 Tahun 2012 Tentang Kedudukan Anak Hasil Zina Dan Perlakuan Terhadapnya menetapkan bahwa Anak hasil zina tidak mempunyai hubungan nasab, wali nikah, waris, dan nafaqah dengan lelaki yang mengakibatkan kelahirannya. 2. Anak hasil zina hanya mempunyai hubungan nasab, waris, dan nafaqah dengan ibunya dan keluarga ibunya.

\section{b. Menurut UU Perkawinan dan KHI}

Kedudukan nasab anak diatur dalam pasal 42 Undang-Undang nomor 1 Tahun 1974 dan Kompilasi Hukum Islam Pasal 99 yang menyebutkan "anak yang sah adalah anak yang dilahirkan dalam atau sebagai akibat perkawinan yang sah.

Sedangkan anak yang dilahirkan di luar perkawinan hanya mempunyai hubungan perdata dengan ibunya dan keluarga ibunya. Sebagaimana dijelaskan pada pasal 43 UU Perkawinan dan pasal 100 Kompilasi Hukum Islam.

Selanjutnya dalam Pasal 44 ayat 1 dan 2 menjelaskan penyangkalan sahnya anak yang terbukti bahwa istrinya berselingkuh dan anak tersebut bukan anak sah suami istri, yaitu Seorang suami dapat menyangkal sahnya anak yang dilahirkan oleh istrinya, bilamana ia dapat membuktikan bahwa istrinya telah perzina dan anak itu akibat daripada perzinaan tersebut. Kemudian pengadilan memberikan keputusan tentang tidaknya anak atas permintaan pihak yang berkepentingan.

\section{Hak Waris}

\section{a. Menurut Hukum Islam}

Waris adalah pemindahan hak kepemilikan harta peninggalan pewaris kepada orang yang mempunyai hubungan darah atau hubungan perkawinan dengan pewaris, dengan syarat tidak ada penghalang terjadinya saling mewarisi. Ada tiga syarat agar supaya orang yang masih hidup dapat mewarisi harta peninggalan orang yang telah meninggal, yaitu:

1. Adanya hubungan darah atau hubungan perkawinan dengan pewaris.

2. Beragama Islam.

3. Tidak terhalang karena hukum untuk menjadi ahli waris.

Salah satu penyebab adanya saling mewarisi adalah Hubungan darah, sedangkan syariat tidak mengakui adanya hubungan darah 
antara anak hasil perzinaan dengan laki-laki yang menyebabkan kelahirannya dan juga keluarga dari laki-laki yang menjadi ayah biologisnya. Tidak adanya hubungan darah tersebut menjadi penghalang terjadinya hak saling mewarisi diantara mereka. Penyebabnya zina bukan jalan yang sah menurut syara' bagi terjalinnya hubungan nasab, sehingga dapat saling mewarisi. Sebaliknya, syariat mengakui adanya hubungan darah antara anak hasil perzinaan dengan ibunya, dan juga keluarga ibunya, sehingga dia berhak mewarisi harta peninggalan ibunya dan juga keluarga ibunya. Jika ibunya meninggal, anak tersebut berhak mewarisi. Juga sebaliknya, jika anak tersebut meninggal maka ibunya berhak mewarisi.

Landasan hukum terhadap ketentuan keperdataan waris anak zina ini disitir dalam hadis, Nabi saw bersabda tentang anak hasil zina: "Bagi keluarga ibunya ..." (HR. Abu Dawud). Dalam hadis lain dari 'Amr ibn Syu'aib ra dari ayahnya dari kakeknya bahwa Rasulullah saw bersabda: Setiap orang yang menzinai perempuan baik merdeka maupun budak, maka anaknya adalah anak hasil zina, tidak mewarisi dan tidak mewariskan" (HR. Al-Turmudzi)

Untuk melindungi anak hasil zina, MUI dalam Fatwa nomor 11/2012 menetapkan kepada laki-laki yang menghamili wanita tersebut untuk mencukupi kebutuhan sang anak dan memberikan memberikan harta setelah ia meninggal melalui wasiat wajibah sebagai ganti waris. Hal ini bertujuan melindungi anak, bukan untuk mensahkan hubungan nasab antara anak tersebut dengan lelaki yang mengakibatkan kelahirannya.

\section{b. Menurut KHI}

Dalam Kompilasi hukum Islam tidak diterangkan secara spesifik tentang hak waris terhadap anak zina. Hanya disebutkan dengan istilah anak dalam perkawinan dan anak di luar perkawinan. Dalam KHI pasal 171 menjelaskan bahwa "Ahli waris adalah orang yang pada saat meninggal dunia mempunyai hubungan darah atau hubungan perkawinan dengan pewaris, beragama Islam dan tidak terhalang karena hukum untuk menjadi ahli waris".

Dalam pasal ini dapat difahami bahwa anak hasil zina tetap mendapatkan warisan dari orangtuanya akibat hubungan perkawinan. Sedangkan anak zina yang lahir di luar perkawinan hanya bernasab kepada ibunya. Sebagaimana pasal Pasal 186 menyebutkan "Anak yang lahir di luar perkawinan hanya mempunyai hubungan saling mewaris dengan ibunya dan keluarga dari pihak ibunya."

\section{Hak Wali}

\section{a. Menurut Hukum Islam}

Salah satu rukun dalam perkawinan adalah adanya wali bagi calon pengantin wanita. Jumhur ulama berpendapat suatu perkawinan tidak sah tanpa kehadiran wali. secara umum yang dimaksud dengan wali adalah seseorang yang karena kedudukannya berwenang untuk bertindak terhadap dan atas nama orang lain. Dalam pernikahan, wali adalah seseorang yang bertindak atas nama mempelai perempuan dalam suatu akad, dimana akad nikah dilakukan oleh dua pihak yaitu mempelai laki-laki dan wali dari pihak perempuan.

Eksistensi seorang wali dalam akad nikah merupakan suatu kemestian, sebab akad nikah tidak sah tanpa adanya seorang wali sebagaimana hadis yang berbunyi "lā nikaha illa bi waliyy”. Di dalam Al-Qur'an juga mengisyarakatkan tentang pentingnya keberadaan wali dalam pernikahan. Antara lain Q.S. Al-Baqarah 232

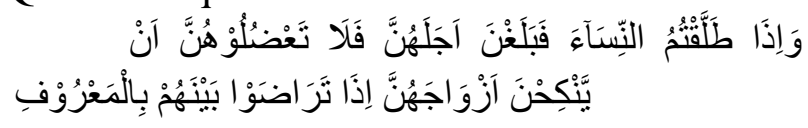

Dan apabila kamu menceraikan istriistri (kamu), lalu sampai idahnya, maka jangan kamu (para wali) halangi mereka menikah (lagi) dengan calon suaminya, apabila telah terjalin kecocokan di antara mereka dengan cara yang baik.....

Dalam Al-Baqarah 221, Allah juga menjelaskan tentang hak seorang wali untuk 
melarang anak perempuannya untuk menikah dengan laki-laki non Muslim.

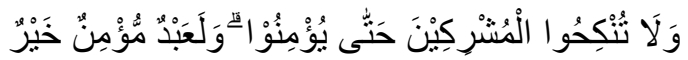

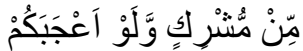

Dan janganlah kamu nikahkan orang (laki-laki) musyrik (dengan perempuan yang beriman) sebelum mereka beriman. Sungguh, hamba sahaya laki-laki yang beriman lebih baik daripada laki-laki musyrik meskipun dia menarik hatimu. ....

Pentingnya keberadaan seorang wali dalam pernikahan juga disebutkan dalam hadis Nabi. Sehingga suatu pernikahan tanpa adanya wali hukumnya tidak sah. Adapun yang berhak menjadi wali adalah:

1. Wali nasab, yaitu yang mempunyai hubungan tali kekeluargaan dengan perempuan yang akan melakukan akad pernikahan.

2. Wali mu'țiq, yaitu orang yang menjadi wali atas perempuan yang pernah menjadi hamba sahaya yang telah dimerdekakan.

3. Wali hakim, yaitu seseorang yang menjadi wali atas perempuan karena kedudukannya sebagai hakim atau penguasa.

Telah diatur dalam Hukum Islam bahwa orang yang menjadi wali anak zina tersebut harus jelas nasab dan identitas wali tersebut, maka dengan demikian Hukum menikahkan anak perempuan zinanya oleh ayah biologisnya tidak diperbolehkan menurut Jumhur Ulama, bahwa pezina tidak boleh menjadi wali nikah anak tersebut, karena anak perempuan zinanya bukan anak sahnya.

Sebagaimana telah panjang lebar di bahas sebelumnya tentang wali dan hubungan nasab antara anak zina dan ayah biologisnya yang tidak diakui oleh agama dan hanya mengakui hubungan antara anak dan ibu serta keluarga ibu, maka ayah dan keluarga ayah tidak dapat menjadi wali dalam pernikahan anak perempuan biologisnya. Dengan demikian maka perwalian pindah dari wali nasab menjadi di tangan wali hakim.

\section{b. Menurut UU Perkawinan dan Kompilasi Hukum Islam}

Dalam Undang-Undang No. 1 Tahun 1974 tentang Perkawinan Pasal 50 ayat 1 dan 2, Pasal 51 ayat 1 dan 2, bahwa anak hasil zina juga memiliki hak perwalian yang ditunjuk dari salah satu orang tuanya, karena anak tersebut tidak berada di bawah kekuasaan ayah biologisnya dan menjalankan segala tugas perwalian seperti tugas orang tua, yaitu Anak yang belum mencapai umur 18 (delapan belas) tahun atau belum pernah melangsungkan perkawinan, yang tidak berada di bawah kekuasaan orang tua, berada di bawah kekuasaan wali. Dan Perwalian itu mengenai pribadi anak yang bersangkutan maupun harta bendanya. Wali dapat ditunjuk oleh satu orang tua yang menjalankan kekuasaan orang tua, sebelum ia meninggal, dengan surat wasiat atau dengan lisan di hadapan 2 orang saksi. Wali sedapat-dapatnya diambil dari keluarga anak tersebut atau orang lain yang sudah dewasa, berpikiran sehat, adil, jujur dan berkelakuan baik.

Dalam KHI pasal 19, kedudukan Wali Nikah dalam perkawinan merupakan rukun yang harus dipenuhi bagi calon mempelai wanita yang bertindak untuk menikahkannya. Syarat tentang wali nikah dijelaskan pada Pasal 20 seorang laki-laki yang memenuhi syarat hukum Islam yakni muslim, aqil dan baligh.

Yang paling berhak untuk menikahkan adalah wali nasab sesuai dengan urutan kedudukan yang dijelaskan pada pasal 21 . Sedangkan pada pasal 23 menyebutkan bahwa Wali hakim baru dapat bertindak sebagai wali nikah apabila wali nasab tidak ada atau tidak mungkin menghadirkannya atau tidak diketahui tempat tinggalnya atau gaib atau adlal atau enggan.

Sebagaimana yang dijelaskan pada pasal 99 KHI, bahwa anak yang sah adalah yang dilahirkan dalam atau akibat perkawinan yang sah. Maka status ayah biologis si anak zina tersebut tidak ada halangan menjadi wali nikah, sebab dianggap sebagai anak yang sah dari hasil perkawinan yang sah. 


\section{SIMPULAN}

Allah mengharamkan zina dengan tujuan untuk menghindarkan manusia dari keburukan baik di dunia terlebih lagi di akhirat. Karenanya Allah memberikan sanksi yang keras bagi pelaku zina yaitu hukuman dera bagi pezina yang belum menikah (ghairu muhșan) dan hukum rajam bagi pezina yang sudah menikah (muhșan). Dan dalam Al-Qur'an Allah mengharamkan orang yang beriman menikah dengan seorang pezina

Pada dasarnya anak yang dilahirkan adalah suci dan tidak menanggung dosa siapapun, sekalipun ia terlahir sebagai hasil zina. Status sebagai anak zina atau sering disebut anak haram adalah akibat dosa zina yang dilakukan oleh perempuan dan laki-laki yang melanggar larangan Allah dengan melakukan perbuatan zina.

Terkait dengan hukum kawin hamil para ulama berbeda pendapat, Imam Hanafi dan Syafi'i membolehkan menikahinya, hanya saja Hanafi tidak membolehkan untuk berhubungan seksual sampai anak yang dikandung lahir. Sementara Imam Malik dan Imam Hanbali tidak membolehkan menikahi wanita hamil akibat zina kecuali setelah bertaubat dan melewati masa iddah. Sedangkan dalam kompilasi Hukum Islam membolehkan seorang wanita kawin dengan pria yang menghamilinya, tanpa menunggu lebih dahulu kelahiran anaknya. dan tidak diperlukan perkawinan ulang setelah anak yang dikandung lahir.

Istilah anak zina didefinisikan berbeda antara pengertian dalam hukum Islam dan dan UU Perkawinan maupun KHI. Perbedaan definisi menyebabkan perbedaan dalam hukum. Dalam hukum Islam anak zina adalah anak yang dilahirkan karena hubungan laki-laki dan perempuan di luar nikah. Anak hasil zina dinasabkan hanya kepada ibunya, ia tidak mendapatkan hubungan perdata dengan ayah biologisnya sehingga ia tidak berhak mewarisi, dan sang ayah biologis tidak berhak menjadi wali nikah.

Sedangkan dalam UU Perkawinan dan KHI status anak dapat dikategorikan kepada tiga:

1. Anak yang sah. yaitu anak yang dilahirkan dalam atau sebagai akibat perkawinan yang sah.

Dalam pemahaman penulis bahwa ketika seorang wanita hamil akibat zina, anak yang dikandungnya dapat dinasabkan kepada ibu dan ayah biologisnya asalkan ia lahir dalam perkawinan yang sah. Maka ia berhak untuk saling mewarisi dengan ayah ibunya, dan ayahnya berhak menjadi wali dalam pernikahannya.

\section{Anak di luar Perkawinan.}

Yang dimaksud dengan anak yang lahir di luar perkawinan adalah anak yang dilahirkan di luar perkawinan yang sah atau akibat hubungan yang tidak sah. Status anak di luar perkawinan, hanya memiliki hubungan perdata dengan ibunya.

\section{Anak Zina.}

Yaitu anak yang disangkal oleh suami dengan menuduh istrinya berzina dan anak itu lahir akibat dari perzinaan tersebut. Maka status anak zina tidak dapat dinasabkan kepada ayahnya dan tidak memiliki hubungan keperdataan dengan ayahnya.

\section{DAFTAR PUSTAKA}

Ali, Zainuddin. Hukum Perdata Islam di Indonesia, Cet. I; Palu: Yayasan Masyarakat Indonesia baru, 2002.

Fuady, Munir. Konsep Hukum Perdata, Cet. Ke-2 Jakarta: PT. RajaGrafindo Persada, 2015.

Gerungan, W.A., Psikologi Sosial, Bandung: Rafika Aditama, 2004.

Ghazaly, Abd. Rahman, Fiqih Munakahat, Jakarta: Kencana Prenada Media Grup, 2003

Jaib, Sa'adi Abu. Al-Qamus al-Fiqhi Lughatan wa Istilahan, Damaskus: Darul Fikr, 1988. 
Jaziri, Abdurrahman Al. Al Fiqh 'Ala Madzahibul Arba`ah, Beirut: Darul Haya At Turb Al Araby, 1969

Jurjani, Ali bin Muhammad bin Ali Al-. alTa'rifat, Beirut: Dar al-Kutub al-Ilmiyah, 1983

Khatib, Yahya Abdurrahman Al-, Fikih Wanita Hamil, Jakarta: Qisthi Press, 2006.

Mahyuddin, Masailul Fiqhiyah, Jakarta: Kalam Mulia, 2008.

Mawardhi, Abu Hasan, Ali bin Muhammad bin Muhammad bin Habib al- al-Hawi alKabir fi fiqhi Madzhahib al-Imam AsSyafi'I, Beirut, Darul Kutub alllmiyah, 1994.
Nawawi, Imam Abi Zakarya Muhyiddin Bin Syarfu. Majmu' Syarah Muhazzab, Lebanon: Dar Al-Fikr, 2005

Usman bin Ali, Tabyin al- Haqaiq Syarhu Kanzu al-Daqaiq wa Hasyiyatu al-Syibli, Kairo, al- Matba'ah al Kubra al-Amiriyah, $1313 \mathrm{H}$.

Yanggo, Chuzaimah T. dan Hafiz. Probematika Hukum Islam Kontemporer, Jakarta: Logos Wacana Ilmu, 2002

Zein, Eko. Asmar Yetti dan Suryani. Psikologi Ibu dan Anak. Yogyakarta: Fitramaya, 2005.

Zuhaili, Wahbah Az-. Fiqih Islam wa Adillatuhu, Penerjemah, Abdul Hayyie alKattani, dkk; penyunting, Budi Permadi, Jakarta: Gema Insani, 2011. 